\title{
Feasibility of Balcony Wall-Mounted Solar Water Heating System in High-Rise Residential Buildings
}

\author{
Zhiyong Zhou ${ }^{1, *}$, Yiqin $\mathrm{He}^{1}$, Jia $\mathrm{Lu}^{2}$ and Xiaochen $\mathrm{Zhang}^{1}$ \\ ${ }^{I}$ Faculty of Civil Engineering and Mechanices, Kunming University of Science and Technology, Kunming 650500, China \\ ${ }^{2}$ Graduate School of Business, SEGI University, Selangor 47810, Maylasia \\ Received 7 August 2019; Accepted 29 November 2019
}

\begin{abstract}
The application of a solar water heating system is severely restricted by the limited roof area of high-rise buildings in urban areas. Therefore, the installation of a balcony wall-mounted solar water heating system (BWSWHS) on the facades of buildings has become an alternative solution. Annual conventional energy consumption and dynamic cost of three types of water heating systems were compared to prove the technical and economic feasibility of the BWSWHSs. First, the field measurement of the BWSWHS was conducted. Then, according to the principle of maximizing sunshine duration, the azimuth angle (AZ) of the building, suitable facade for installation, and optimal inclination angle of the collector were determined through sunshine simulation. Next, the annual heat gain and conventional energy consumption of the BWSWHSs were obtained from simulation using a verified model. Finally, annual energy consumption and dynamic cost of three types of water heating systems, namely, BWSWHS, electric and natural gas water heating systems, were compared. Results show that the optimal AZ of the building is $30^{\circ}$ south by east, the suitable façade for installation is south, and the optimal inclination angle of the collector is $70^{\circ}$. In this case, the thermal efficiency of the collector is $44 \%$ and the solar fraction is $41 \%$. Annual conventional energy consumption and dynamic cost are lower than that of the two other systems. The present study provides a basis for the promotion of the BWSWHS in residential high-rise buildings.
\end{abstract}

Keywords: Balcony wall-mounted solar water heating system, Performance optimization, Feasibility

\section{Introduction}

The technical means of building energy conservation mainly include the implementation of building energy-efficient equipment, the use of renewable energy, and the promotion of behavioral energy-saving by enhancing user awareness. The application of solar energy has effectively reduced building energy consumption due to developed technology and low cost. Considering the low cost and high thermal performance, solar water heating systems are more popular than solar photovoltaic systems. Therefore, solar water heating systems have been widely adopted in areas with sufficient sunshine. According to statistics from the International Energy Agency, the area of solar energy collectors worldwide was 535 million square meters as of 2013, most of which were in China and Europe. The two regions accounted for $82 \%$ of the world's total area. Meanwhile, $94 \%$ of households' heating needs were provided by the solar water heating system, which accounted for $1.2 \%$ of the domestic hot water and heating.

The rapid development of cities has led to land shortage, and most of the new residential buildings in those areas are high-rise buildings. However, their roof area is insufficient to accommodate the installation of traditional roof solar water heating systems (RSWHS) because equipment rooms and tube wells must be placed on the roof. Thus, RSWHS cannot supply sufficient hot water and heating.

*E-mail address: zhiy_zhou@163.com

ISSN: 1791-2377 @ 2019 School of Science, IHU. All rights reserved. doi:10.25103/jestr.126.18
Therefore, some scholars shifted their attention to the application of balcony wall-mounted solar water heating systems (BWSWHSs) in residential buildings [1] [2]. However, most scholars still focused on the RSWHS [3] [4] [5]. Other scholars shifting to BWSWHS are interested in their thermal performance [6] [7] [8] [9]. Compared with RSWHS, BWSWHS incurs additional purchase expenses and gains less solar. Hence, the feasibility of BWSWHS is crucial to their promotion.

Kunming City was selected as the study site because of its abundant solar energy resources and mild climate. The thermal performance of BWSWHS in a high-rise residential building was tested for three days and simulated for an entire year. The annual energy consumption and costs of various water heating systems were compared to verify the feasibility of the BWSWHS in high-rise residential buildings.

\section{State of the Art}

Flat-plate collectors were mostly selected for BWSWHSs in southern China because of the local climate conditions as well as durability and aesthetics [10] [11]. Scholars focused on two aspects of BWSWHS with flat-panels.

The first aspect considers the collector or the water tank of BWSWHS. Li et al. [12] compared the thermal performance of BWSWHSs with flat-panel or all-glass vacuum tube collectors on the condition of different arrangements and water circulation, which excluded 
economic analysis. Cerón et al. [13] developed a threedimensional numerical model of flat-plate collectors, which can be used to predict the efficiency curve of the collectors under different heat transfer modes; however, they did not conduct empirical research. Jilani and Thomas [14] obtained the annual thermal performance data of flat-plate and allglass vacuum tube collectors from a site test but did not analyze system performance. Fazilati and Alemrajabi [15] used phase change material as a storage medium for BWSWHS, but the study was limited to experiments. Bouhal et al. [16] simulated the phenomenon of hot water stratification in the heat collecting tank but did not conduct empirical verification.

The second aspect pertains to the entire BWSWHS. Liao and Wei [17] deduced the relationship between installation and solar altitude angles of BWSWHS and confirmed the appropriate installation angle of collectors. However, the mutual shielding problem due to the installed collectors in high-rise buildings was ignored. Wei et al. [18] calculated the volume of water tanks and solar fraction of BWSWHSs in nine cities in temperate regions using their mathematical model, but the analysis of system performance and the economy was neglected. Shen [19] proposed methods on the integration of building design and BWSWHS, but the same deficiency existed as that of the former study. ZambranaVasquez et al. [20] calculated the life-cycle carbon emission of BWSWHS but ignored the economic analysis for each user. Fertahi et al. [21] attempted to optimize the thermal performance of BWSWHS but omitted the annual thermal performance. Naspolini and Ruther [22] demonstrated that BWSWHS could effectively cut down power supply load based on simulation; however, they did not present sufficient detailed analysis. Comodi et al. [23] compared the carbon emission and economy of BWSWHSs with different encapsulated modes, but their conclusion lacked site measurement data for support.

Overall, scholars have either focused on the thermal performance of BWSWHS or its components based on experiments or measurements or the carbon emission or economy of the BWSWHS based on simulations. The present study attempted to combine the two aforementioned aspects. Therefore, a simulation model verified by the measured data of the BWSWHS is established. Then, the annual thermal performance of the system is obtained with the established model. Finally, its economy and energy saving are compared with those of the two other water heating systems. The BWSWHS is proven to be feasible in high-rise residential buildings.

The rest of this study is organized as follows. The third section presents the optimization design method of BWSWHS and builds the TRNSYS model for the simulation of thermal performance. The fourth section discusses the calculation of the annual converted energy consumption and dynamic cost of three different types of water heating systems based on the annual energy consumption of BWSWHS from the TRNSYS simulation. The last section summarizes this study and provides relevant conclusions.

\section{Methodology}

\subsection{Arrangement of field measurement}

A residential community in Kunming City was selected for field measurement. The community comprises three 33-story residential buildings, and each building houses six families on each floor with 2.5 persons in each family. The
Guidelines for Integration Design of Solar Water Heating System and Building in Kunming stipulates that the true solar hour of BWSWHS must not be less than $4 \mathrm{~h}$ from 8 a.m. to 6 p.m. during the winter solstice. Therefore, according to the results of the sunshine analysis on the winter solstice day (Fig. 1), the households that meet the above stipulation were selected for measurement. The BWSWHS and relevant test equipment were set on the balcony (Fig. 2). The azimuth (AZ) of the balcony is $16.15^{\circ}$ south by west. The measurement period was from 8 a.m. of the day to 8 a.m. of the next day on April 2nd, 4th, and 20th in 2017. The relevant parameters of devices for the field measurements are shown in Table 1. The auxiliary heat source is electric.

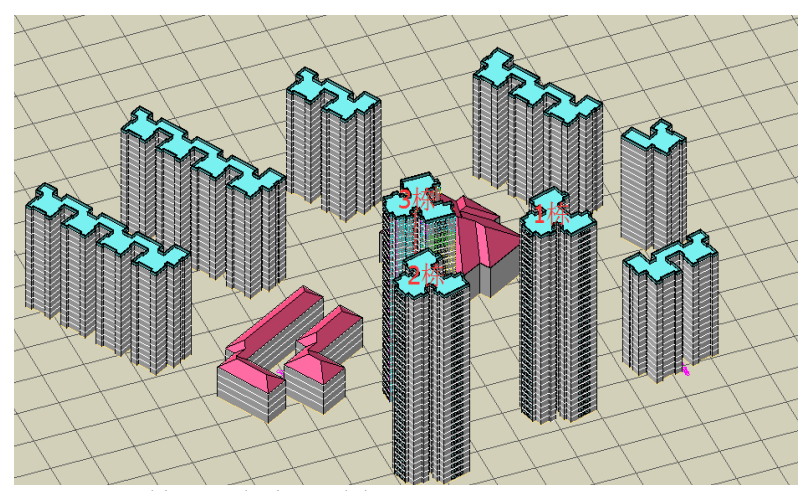

Fig. 1. Sunshine analysis model

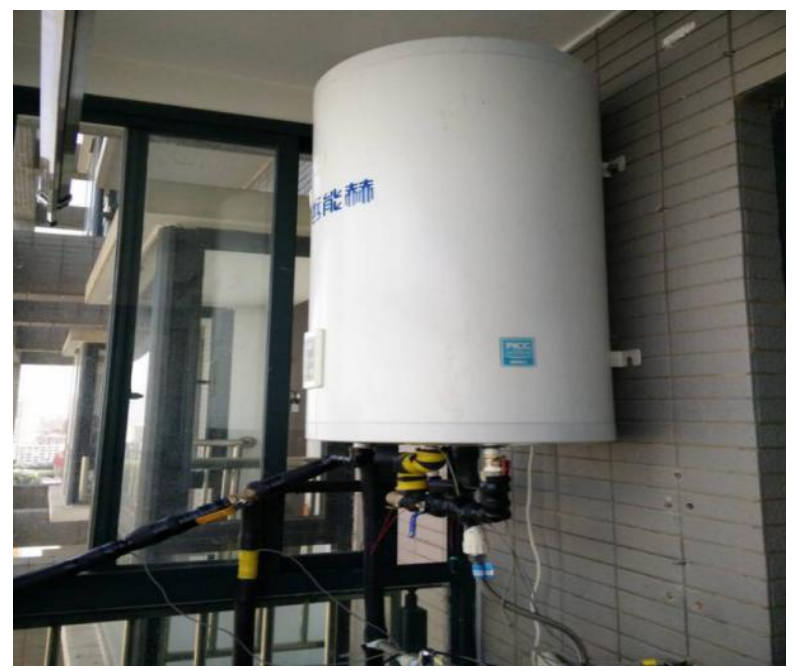

Fig. 2 Schematic of test equipment

Table 1. Parameters of BWSWHS

\begin{tabular}{c|c|c}
\hline Component & Parameter type & Parameter values \\
\hline \multirow{2}{*}{$\begin{array}{c}\text { solar thermal } \\
\text { collector }\end{array}$} & area (S) & $2.7 \mathrm{~m}^{2}$ \\
& inclination angle $(\alpha)$ & $60^{\circ}$ \\
\multirow{3}{*}{ water tank } & type & $16.15^{\circ}$ south by west \\
& volume $\left(V_{s}\right)$ & vertical type \\
& height $(h)$ & $120 \mathrm{~L}$ \\
\hline
\end{tabular}

3.2 Calculation of the thermal performance parameters based on field measurement data

The data of field measurement include air temperature, humidity, and wind speed of the balcony, average initial and final temperature of the heat storage tank, and total amount of solar radiation on the surface of collectors. According to the Evaluation Criteria for Building Application of Renewable Energy GBT50801-2013, the following formula is adopted to calculate the parameters. 
The heat gain of BWSWHS $\left(Q_{u}\right)$ is calculated by the following equation:

$Q_{u}=\rho_{w} C_{p} V_{s}\left(T_{e}-T_{\mathrm{b}}\right) \times 10^{-3}$

where $Q_{u}$ is the heat gain of BWSWHS (MJ), $\rho_{w}$ is the density of water $\left(1000 \mathrm{~kg} / \mathrm{m}^{3}\right), C_{p}$ is the specific heat of water at constant pressure $\left(4.187 \mathrm{~kJ} /\left(\mathrm{kg} .{ }^{\circ} \mathrm{C}\right)\right), V_{s}$ is the volume of heat storage tank $\left(\mathrm{m}^{3}\right), T_{b}$ is the average initial temperature of heat storage tank $\left({ }^{\circ} \mathrm{C}\right)$, and $T_{e}$ is the average final temperature of heat storage tank $\left({ }^{\circ} \mathrm{C}\right)$.

The thermal efficiency of BWSWHS $\left(\eta_{\mathrm{s}}\right)$ is calculated by the following equation:

$\eta_{\mathrm{s}}=\frac{Q_{u}}{H} \times 100 \%$

where $\mathrm{H}$ is the total amount of solar radiation on the plane of collector (MJ).

The average heat loss factor of water tank is calculated by the following equation:

$U_{\mathrm{sl}}=\frac{\rho_{w} C_{p}}{\Delta \tau} \ln \left[\frac{t_{i}-t_{a s(a v)}}{t_{f}-t_{a s(a v)}}\right]$

where $U_{\mathrm{sl}}$ is the heat loss factor of water tank $\left(\mathrm{W} /\left(m^{3} . \mathrm{K}\right)\right)$, $\Delta \tau$ is the duration from 8 p.m. of the day to 6 a.m. of the next day $(\mathrm{s}), t_{i}$ is the average temperature of the heat storage tank at the beginning $\left({ }^{\circ} \mathrm{C}\right), t_{f}$ is the average temperature of the heat storage tank at the end $\left({ }^{\circ} \mathrm{C}\right)$, and $t_{a s(a v)}$ is the average air temperature for the duration $\left({ }^{\circ} \mathrm{C}\right)$.

\subsection{Building the simulation model}

TRNSYS was used to obtain the annual thermal performance of the system because the field measurement merely lasted for three days. First, the TRNSYS model and the relevant parameters were set according to the measured system (Fig. 3 and Table 2). Then, the three-day outdoor environment parameters measured were taken as the meteorological parameters for the simulation. Finally, the simulated thermal performance parameters were compared with the measured data to determine the accuracy of the simulation. If the error is within the acceptable range, then the model can be used for annual simulation.

\subsection{Total Amount of annual heat gain of BWSWHS}

A 33-story building, which has eight households on each floor, was selected for the present study. Varied shading effects were derived from the diverse AZs of the building. Thus, four AZs, including due south, $30^{\circ}, 45^{\circ}$, and $60^{\circ}$ south by east ( $\mathrm{SbE})$, were considered. Winter and summer solstice are the two respective time points of minimum and maximum solar elevating angle in Kunming. Consequently, the sunshine conditions of each balcony on the four facades at five AZs on winter solstice (December 22nd in a typical meteorological year) and summer solstice (June 21st in a typical meteorological year) were analyzed separately. Fig. 4 shows the model of the sunshine simulation analysis.

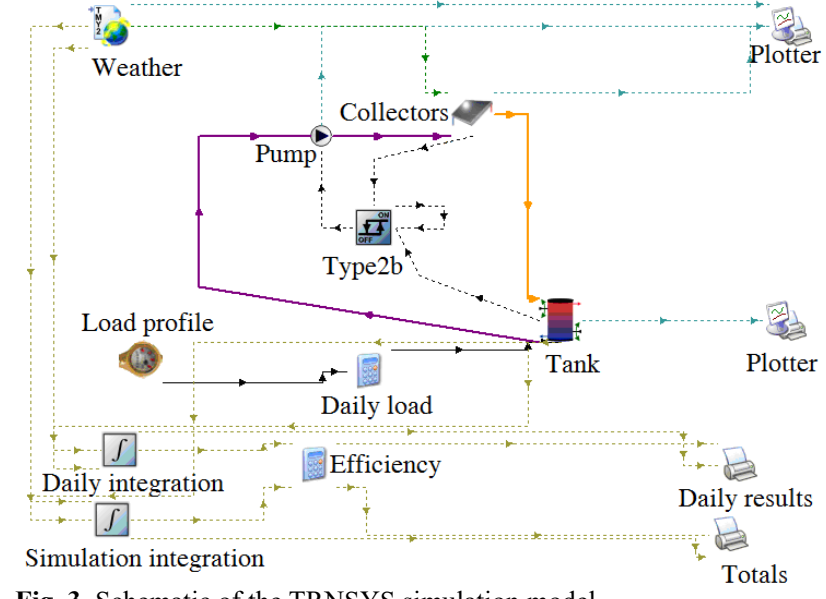

Fig. 3. Schematic of the TRNSYS simulation model

Table 2. Parameters of the TRNSYS simulation model

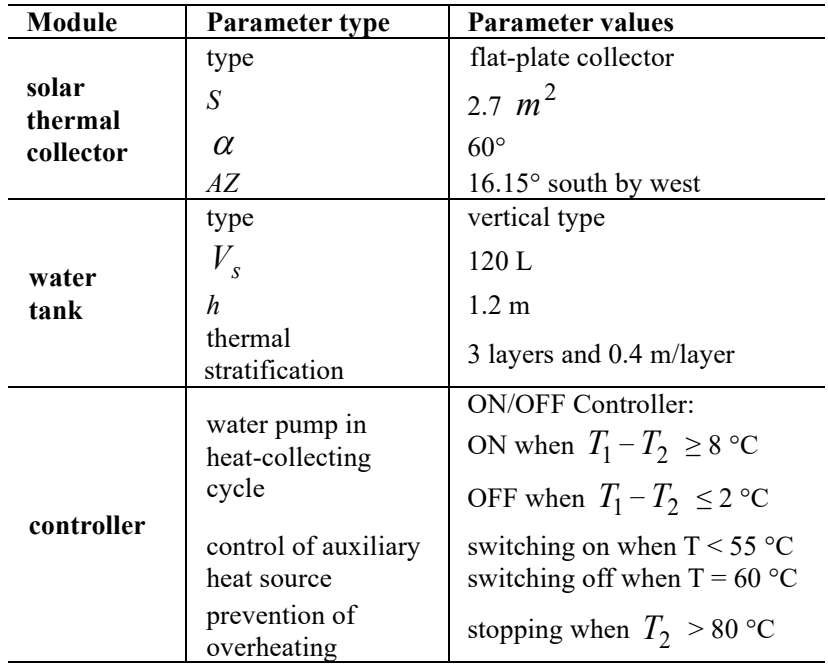

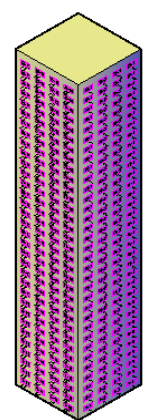

Fig. 4. Model for sunshine simulation analysis

The collector on the upper floor should shade the one on the lower floor. Therefore, the shielding effect must be considered when analyzing the sunshine duration of the BWSWHS. The collectors were regarded as the sunshade on the building facade to simplify the analysis. The size of flatplate collectors is $1 \mathrm{~m} \times 2 \mathrm{~m}$. Therefore, the overhanging length of the sunshade is $\mathrm{m}$. The sunshine simulations were conducted on the condition of adding those sunshades (Fig. 4). Finally, the optimal inclination angle was determined according to the principle of maximizing sunshine duration of the balconies.

The collector on the upper floor should shade the one on the lower floor. Therefore, the shielding effect must be considered when analyzing the sunshine duration of the BWSWHS. The collectors were regarded as the sunshade on the building facade to simplify the analysis. The size of flat- 
plate collectors is $1 \mathrm{~m} \times 2 \mathrm{~m}$. Therefore, the overhanging length of the sunshade is $\mathrm{m}$. The sunshine simulations were conducted on the condition of adding those sunshades (Fig. 4). Finally, the optimal inclination angle was determined according to the principle of maximizing sunshine duration of the balconies.

After the optimal AZ of the building and the inclination angle of the collector were determined and the domestic hot water consumption was set, the verified TRNSYS model was used to obtain $\mathrm{H}, Q_{u}, \eta_{\mathrm{s}}, Q_{t}, Q_{a}$, and $\mathrm{f}$ of BWSWHSs for the entire year. Then, the annual heat gain of the BWSWHSs and the heat supply of the auxiliary heat source, which are the fundamental data for the next comparative analysis, were calculated.

\subsection{Comparative analysis of energy consumption and economic efficiency}

Based on the above results, the annual energy consumption $(E)$, the converted annual energy consumption $\left(E_{c e}\right)$, and the dynamic annual cost $\left(Z_{d}\right)$ were compared among BWSWHSs and electric and natural gas water heating systems (EWHS and GWWHS). The relevant fundamental data are as follows: the purchase prices of the three water heating systems are $\$ 495, \$ 353$, and $\$ 283$. The actual calorific value of natural gas and electricity with the thermal efficiency of 0.8 and 0.9 were set at $28.44 \mathrm{MJ} / \mathrm{N} \mathrm{m}{ }^{3}$ and $3.24 \mathrm{MJ} / \mathrm{kWh}$, respectively. The conversion factors of coal equivalent were set at $1.2143 \mathrm{kgce} / \mathrm{N} \mathrm{m}^{3}$ and 0.308 $\mathrm{kgce} / \mathrm{kWh}$, and the prices were set at $\$ 0.42 / \mathrm{N} \mathrm{m}^{3}$ and $\$ 0.06 / \mathrm{kWh}$, respectively. The exchange rate is set at 0.1413 . In addition, $30 \%$ of the local power supply is derived from thermal power generation (coal consumption of 0.308 $\mathrm{kgce} / \mathrm{kWh}$ ) and $70 \%$ is from hydropower generation (coal consumption of $0.004 \mathrm{kgce} / \mathrm{kWh}$ ).

The annual dynamic cost is calculated by the following equation:

$Z_{d}=K \frac{i(1+i)^{n}}{(1+i)^{n}-1}+C_{m}+C_{e}$

where $Z_{d}$ is annual dynamic cost (dollar), $\mathrm{i}$ is discount rate (4.9\% of long-term loan interest rate), $\mathrm{K}$ is aggregate investment cost (dollar), $C_{m}$ is annual maintenance cost ( $2 \%$ of purchase price, dollar), $C_{e}$ is annual energy cost (dollar), and $\mathrm{n}$ is the effective life of the system ( 15 years).

\section{Results Analysis and Discussion}

\subsection{Analysis of field measurement data}

The thermal performance parameters were obtained through Eqs. (1)-(3) based on the date of the field measurement in Section 3.1 (Table 3). The results illustrate that the different environmental parameters will exhibit different and Therefore, the field measurement of the entire year is impractical due to heavy workload and unpredictable environmental parameters. Thus, TRNSYS simulation is practical and feasible on the condition that the model can pass error verification.

\subsection{Establishment of TRNSYS simulation model}

Through the TRNSYS model in Section 3.3, the simulation results (Table 4) were obtained under the same environmental conditions as the field measurement. Thus, air temperature, humidity, wind speed, total solar radiation, and heat loss factor of the water tank during the test period were used in the simulation. The comparison of the results in Tables 3 and 4 indicates that the difference between simulation and measured results is within $\pm 7 \%$, and the accuracy of the simulation is within the acceptable range. Therefore, TRNSYS simulation can be used for the annual thermal performance of BWSWHS.

Table 3. Thermal performance parameters of the tested BWSWHS

\begin{tabular}{c|c|c|c|c}
\hline Date & $H / \mathrm{MJ}$ & $Q_{u} / \mathrm{MJ}$ & $\eta_{\mathrm{s}} / \%$ & $U_{\mathrm{sl}} /\left(\mathrm{W} / m^{3} . \mathrm{K}\right)$ \\
\hline $2 / 4 / 2017$ & 20.13 & 8.42 & 41.74 & 15.5 \\
$4 / 4 / 2017$ & 21.19 & 7.89 & 40.29 & 18.9 \\
$20 / 4 / 2017$ & 20.47 & 7.87 & 38.55 & 16.2 \\
\hline
\end{tabular}

Table 4. Simulation results under testing conditions

\begin{tabular}{c|c|c|c}
\hline Date & $\boldsymbol{H} / \mathbf{M J}$ & $Q_{u} / \mathbf{M J}$ & $\eta_{\mathrm{s}} / \mathbf{\%}$ \\
\hline $2 / 4 / 2017$ & 20.13 & 7.89 & 39.20 \\
$4 / 4 / 2017$ & 21.19 & 8.04 & 37.94 \\
$20 / 4 / 2017$ & 20.47 & 7.51 & 36.69 \\
\hline
\end{tabular}

4.3 Optimal AZ of the building and suitable facade for installation

Using the sunshine simulation model in Section 3.4, the sunshine durations of the balconies on south, east, and west facades under four different AZs of the building on winter and summer solstice were obtained. The results (Tables 5 and 6) demonstrate the following: the balconies on the south and west facades met the sunshine requirement on winter solstice; the balconies on the south facade met the requirement on summer solstice; the sunshine duration of balconies on the south facade on summer solstice was under the $\mathrm{AZ}$ of $30^{\circ} \mathrm{SbE}$ was longer than that under the $\mathrm{AZ}$ of $45^{\circ}$ $\mathrm{SbE}$. Overall, the optimal AZ of the building is SbE30, and the south facade is a suitable facade for installation.

Table 5. Suitable balconies and their sunshine durations on winter solstice

\begin{tabular}{l|l|l|l|l|l|l}
\hline \multirow{2}{*}{ AZ/ } & \multicolumn{3}{|l|}{$\begin{array}{l}\text { Number of balconies } \\
\text { meeting the requirement }\end{array}$} & \multicolumn{3}{|l}{ Sunshine duration/h } \\
\cline { 2 - 7 } & $\begin{array}{l}\text { South } \\
\text { facade }\end{array}$ & $\begin{array}{l}\text { East } \\
\text { facade }\end{array}$ & $\begin{array}{l}\text { West } \\
\text { facade }\end{array}$ & $\begin{array}{l}\text { South } \\
\text { facade }\end{array}$ & $\begin{array}{l}\text { East } \\
\text { facade }\end{array}$ & West facade \\
\hline $\mathrm{S}$ & 66 & 66 & 66 & 9.22 & 4 & 5.22 \\
$30^{\circ} \mathrm{SbE}$ & 66 & 0 & 0 & 5.5 & 0 & 3.5 \\
$45^{\circ} \mathrm{SbE}$ & 66 & 0 & 66 & 4.5 & 0 & 4.5 \\
$60^{\circ} \mathrm{SbE}$ & 0 & 0 & 66 & 3.5 & 0 & 5.5 \\
\hline
\end{tabular}

Table 6. Suitable balconies and their sunshine durations on summer solstice

\begin{tabular}{l|l|l|l|l|l|l}
\hline \multirow{2}{*}{ AZ $/ \circ$} & \multicolumn{4}{l|}{$\begin{array}{l}\text { Number of balconies } \\
\text { meeting } \\
\text { requirement }\end{array}$} & \multicolumn{3}{|l}{ the } & \multicolumn{3}{l}{ Sunshine duration /h } \\
\cline { 2 - 7 } & $\begin{array}{l}\text { South } \\
\text { facade }\end{array}$ & $\begin{array}{l}\text { East } \\
\text { facade }\end{array}$ & $\begin{array}{l}\text { West } \\
\text { facade }\end{array}$ & $\begin{array}{l}\text { South } \\
\text { facade }\end{array}$ & $\begin{array}{l}\text { East } \\
\text { facade }\end{array}$ & West facade \\
\hline $\mathrm{S}$ & 0 & 0 & 0 & 2.92 & 1.5 & 1.5 \\
$30^{\circ} \mathrm{SbE}$ & 66 & 0 & 0 & 4.38 & 0 & 1.9 \\
$45^{\circ} \mathrm{SbE}$ & 66 & 0 & 0 & 4.3 & 0 & 1.95 \\
$60^{\circ} \mathrm{SbE}$ & 0 & 0 & 0 & 4.5 & 0 & 2.03 \\
\hline
\end{tabular}




\subsection{Optimal inclination angle of collectors}

The optimal of the collector is between $30^{\circ}$ and $70^{\circ}$. A wide inclination angle of the collector is satisfactory only when the shading is considered. However, a narrow angle is satisfactory when the solar elevating angle of the summer solstice is considered. Consequently, sunshine analysis under the inclination angle of $30^{\circ}$ and $70^{\circ}$ should be respectively conducted on the condition of the optimal AZ of the building and suitable façade to determine the optimal inclination angle. The simulation results (Table 7) reveal the following conclusions. Under the inclination angle of $70^{\circ}$, 64 balconies are unable to meet the sunshine requirement for 195 days (from May 5th to August 7th), and the sunshine duration on the summer solstice is $3.18 \mathrm{~h}$ for balconies from the first to $32 \mathrm{nd}$ floor. Under the inclination angle of $30^{\circ}, 64$ balconies are unable to meet the sunshine requirement for 156 days (from April 5th to September 7th), and the sunshine duration on the summer solstice is $1.32 \mathrm{~h}$ for balconies from the first $\mathrm{t}$ to $32 \mathrm{nd}$ floor. Therefore, the optimal inclination angle of collectors is $70^{\circ}$.

Table 7. Sunshine duration of balconies under the different inclination angles

\begin{tabular}{c|c|c|c}
\hline$\alpha$ & Date & $\begin{array}{c}\text { Serial number } \\
\text { of floor }\end{array}$ & $\begin{array}{c}\text { Sunshine Duration of } \\
\text { balconies } / \mathbf{h}\end{array}$ \\
\hline \multirow{7}{*}{$70^{\circ}$} & March & $1-32$ & 4.25 \\
\cline { 2 - 4 } & 5 th & 33 & 5.08 \\
\cline { 2 - 4 } & Summer & $1-32$ & 3.18 \\
& Solstice & 33 & 4.38 \\
\cline { 2 - 4 } & August & $1-32$ & 4.3 \\
& 7 th & 33 & 5.22 \\
\hline \multirow{7}{*}{$30^{\circ}$} & April & $1-32$ & 4.67 \\
& 5 th & 33 & 5.5 \\
\cline { 2 - 4 } & Summer & $1-32$ & 1.32 \\
& Solstice & 33 & 4.38 \\
\cline { 2 - 4 } & September & $1-32$ & 4.12 \\
& 7 th & 33 & 5.5 \\
\hline
\end{tabular}

4.5 Total annual heat gain and conventional energy consumption

Assuming that the average household hot water consumption is $150 \mathrm{~L} / \mathrm{d}$, the annual heat gain and conventional energy consumption of the BWSWHSs were determined by the former verified TRNSYS model using optimal AZ of the building, suitable facade, and optimal inclination angle of the collectors. The results (Table 8) are as follows: the annual gross heating load $\left(Q_{t}\right)$ is $675991.01 \mathrm{MJ} ; Q_{u}$ is $276481.91 \mathrm{MJ}$; conventional energy consumption for the auxiliary heat sources $\left(Q_{a}\right)$ is $399509.10 \mathrm{MJ} ; \eta_{\mathrm{s}}$ is 0.44 ; and solar fraction (f) is 0.41 .

Table 8. Annual simulation results of the 66 BWSWHSs

\begin{tabular}{l|l|l|l|l|l}
\hline \multirow{2}{*}{ Month } & \multicolumn{2}{|l|}{ BWSWHS } & \multirow{2}{*}{$Q_{t} / \mathbf{M J}$} & $Q_{a} / \mathbf{M J}$ & $\boldsymbol{f} / \%$ \\
\cline { 2 - 3 } & $Q_{u} / \mathbf{M J}$ & $\eta_{\mathrm{s}} / \mathbf{\%}$ & & & \\
\hline Jan & 25762.44 & 41 & 65866.88 & 40104.44 & 39 \\
Feb & 28368.78 & 42 & 57746.30 & 29377.52 & 49 \\
Mar & 29244.60 & 45 & 58133.00 & 28888.40 & 50 \\
Apr & 27479.10 & 45 & 52765.02 & 25285.92 & 52 \\
May & 21992.65 & 46 & 53105.98 & 31113.32 & 41 \\
Jun & 17041.27 & 44 & 49771.26 & 32729.99 & 34 \\
Jul & 18155.41 & 48 & 51559.20 & 33403.79 & 35 \\
Aug & 19707.92 & 48 & 51945.89 & 32237.98 & 38 \\
Sep & 21003.84 & 48 & 52141.32 & 31137.48 & 40 \\
Oct & 19383.54 & 46 & 56070.63 & 36687.09 & 35 \\
Nov & 23480.16 & 43 & 60374.16 & 36894.00 & 39 \\
Dec & 24862.20 & 42 & 66511.37 & 41649.17 & 37 \\
annual & 276481.91 & 44 & 675991.01 & 399509.10 & 41 \\
\hline
\end{tabular}

4.6 Comparative analysis among different types of water heating systems

Based on Table 8, Eq. (4), and relevant data in Section 3.5, the annual conventional energy consumption $\left(E_{c}\right)$, annual converted energy consumption $\left(E_{c e}\right)$, and annual dynamic cost $\left(Z_{d}\right)$ of three types of hot water systems were calculated. The result (Table 9) shows that $E_{c e}$ and $Z_{d}$ of BWSWHSs are minimum and those of the electric water heating system are maximum.

Table 9. Index for energy consumption and economy of three types of water heating systems

\begin{tabular}{|c|c|c|c|c|c|}
\hline Type & $E_{c}$ & $\begin{array}{c}E_{c e} \\
/ \mathrm{kgce}\end{array}$ & $\begin{array}{l}C_{e} \\
/ \$\end{array}$ & $\begin{array}{l}C_{m} \\
/ \$\end{array}$ & $\begin{array}{l}Z_{d} \\
/ \$\end{array}$ \\
\hline BWSWHS & $\begin{array}{l}123305 \mathrm{kWh} \\
\text { (Electricity) }\end{array}$ & 11739 & 7398 & 11739 & 11495 \\
\hline EWHS & $\begin{array}{l}208639 \mathrm{kWh} \\
\text { (Electricity) }\end{array}$ & 19862 & 12518 & 198629 & 15440 \\
\hline NGWHS & $\begin{array}{l}23769 \mathrm{~N} \mathrm{~m}^{3} \\
\text { (Natural Gas) }\end{array}$ & 12122 & 9983 & 121229 & 12325 \\
\hline
\end{tabular}

\section{Conclusions}

A TRNSYS model was developed based on field measurement data to verify the feasibility of BWSWHSs in a high-rise residential building. On the condition of the optimal AZ of the building, inclination angle of the collectors, suitable facade, annual heat gain, and conventional energy consumption of BWSWHSs were obtained via simulation. Finally, the annual conventional energy consumption and the dynamic cost of three types of water heating systems were compared. The following conclusions are obtained.

(1) The optimal AZ of the building is determined by maximizing the sunshine durations of the balconies. The sunshine situation on the summer solstice is a decisive factor because the highest solar elevation angle occurs at that time.

(2) The shading of upper to lower floors and solar elevation angle is crucial to determine optimal inclination angle of collectors. The two factors affect the sunshine condition of balconies from opposite aspects.

(3) When the electricity is converted to its coal equivalent, the source of power supply should be considered. Otherwise, the converted coal equivalents are incomparable.

(4) Annual conventional energy consumption and dynamic cost of the BWSWHSs are the lowest among three types of water heating systems. Judging from the two indexes, natural gas water heating system is better than electric water heating system.

Given that field measurement and simulation are combined to obtain the annual energy consumption of the BWSWHSs, the annual conventional energy consumption is accurate and provides a solid basis for the promotion of the system. However, this study is merely based on three days of measured data, and the measurement time should be extended to obtain accurate results.

\section{Acknowledgements}

This work was supported by the National Natural Science Foundation of China (Grant No. 51268020) and the Applied Basic Research Program Foundation of Yunnan Province (Grant No. 2011FZ024). 
This is an Open Access article distributed under the terms of the Creative Commons Attribution License

\section{References}

1. Huang, Y. F., "Implementation procedure and ways of solar energy integration with building". Advanced Materials Research, 450(1), 2012, pp.1405-1408

2. Zhang, J. J., "Study on the integral combination of high-rise residential building and solar water heater". Building Science, 23(4), 2007, pp.101-106.

3. Ogueke, N. V., Anyanwu, E. E., and Ekechukwu, O.V., "A review of solar water heating systems". Journal of Renewable and Sustainable Energy, 1(4), 2009, pp.43-46.

4. Akintola, O. A., and Sangodoyin, A. Y., "Design, development, and performance evaluation of solar heating system for disinfection of domestic roof-harvested rainwater". International Scholarly Research Notices, 15(12), 2015, pp.1-7.

5. Xiang, P., "Application of Solar Water Heating System in Residence". Building Energy Efficiency, 42(4), 2014, pp.26-29.

6. Sutthivirode, K., Namprakai, P., and Roonprasang, N., "A new version of a solar water heating system coupled with a solar water pump". Applied Energy, 86(9), 2009, pp.1423-1430.

7. Akram, N., Sadri, R., Kazi, S. N., et al., "An experimental investigation on the performance of a flat-plate solar collector using eco-friendly treated graphene nanoplatelets-water nanofluids". Journal of Thermal Analysis and Calorimetry, 138(1), 2019, pp.609-621.

8. Bake, M., Shukla, A., Liu, S., et al., "A systematic review on parametric dependencies of transpired solar collector performance". International Journal of Energy Research, 43(1), 2018, pp.86-112.

9. Al-Khaffajy, M., and Mossad, R., "Optimization of the heat exchanger in a flat plate indirect heating integrated collector storage solar water heating system". Renewable Energy, 57(1), 2013, pp.413-421.

10. Peng, Y. J., Wang, L. Zh., Wang, W., et al., "Research progress of flat-plat solar collector". Energy and Energy Conservation, 7(8), 2011, pp.5-7.

11. Zhu, D. Sh., Xu, T., Jiang, X., et al., "Research progress on solar energy collector". Journal of Power Sources, 36(10), 2013, pp. $1582-1584$

12. Li, M., Zheng, T. F., Ji, X., et al., "Performance of facade balcony type solar water heaters". Transactions of the CSAE, 27(10), 2011, pp.228-232.
13. Cerón, J. F., Pérez-García J., Solano J. P., et al., "A coupled numerical model for tube-on-sheet flat-plate solar liquid collectors. Analysis and validation of the heat transfer mechanisms". Applied Energy, 140(2), 2015, pp.275-287.

14. Jilani, G., and Thomas, C, "Effect of thermo-geometric parameters on entropy generation in absorber plate fin of a solar flat plate collector". Energy, 70(3), 2014, pp.35-42.

15. Fazilati, M. A., and Alemrajabi, A. A., "Phase change material for enhancing solar water heater, an experimental approach". Energy Conversion \& Management, 71(7), 2013, pp.138-145.

16. Bouhal, T., Fertahi, S., Agrouaz, Y., et al., "Numerical modeling and optimization of thermal stratification in solar hot water storage tanks for domestic applications: CFD study". Solar Energy, 157(11), 2017, pp.441-455.

17. Liao, N. X., and Wei, Y., "Installation angle and heat analysis of the balcony type solar energy water heater in Guanxi area". Popular Science \& Technology, 14(12), 2012, pp.103-106.

18. Wei, Sh. X., Hu, F. N., and Yan, C. Q., "Optimization of tankvolume to collector-area ratio for balcony wall-mounted flat-plate solar water heater in mild region of China". Transactions of the Chinese Society of Agricultural Engineering, 32(3), 2016, pp.195201.

19. Shen, W., "Balcony wall type solar water heaters: promote the combination of solar water heaters and building energy efficiency". Transactions of the CSAE, 22(1), 2006, pp.194-198.

20. Zambrana-Vasquez, D., Aranda-Usón, A., Zabalza-Bribián, I., et al., "Environmental assessment of domestic solar hot water systems: a case study in residential and hotel buildings". Journal of Cleaner Production, 88(3), 2014, pp.29-42.

21. Fertahi, S., Bouhal, T., Gargab, F., ea al., "Design and thermal performance optimization of a forced collective solar hot water production system in Morocco for energy saving in residential buildings". Solar Energy, 160(1), 2018, pp.260-174.

22. Naspolini, H. F., and Rüther, R., "The effect of measurement time resolution on the peak time power demand reduction potential of domestic solar hot water systems". Renewable Energy, 88(3), 2016, pp.325-332.

23. Comodi, G., Bevilacqua, M., Caresana, F., et al., "Life cycle assessment and energy-CO2-economic payback analyses of renewable domestic hot water systems with unglazed and glazed solar thermal panels". Applied Energy, 164(2), 2016, pp.944-955. 